\title{
EVENT BASED ASSESSMENT: A FORMATIVE ASSESSMENT OF INTEGRATED CHARACTER EDUCATION
}

\author{
Ni Made Sri Mertasari ${ }^{1}$, Made Yudana ${ }^{2}$, Nyoman Gita ${ }^{3}$ \\ Ganesha University of Education \\ Mathematics Education Department, Civic Education Department, Mathematics Education Department \\ srimertasari@undiksha.ac.id ${ }^{1}$, made.yudana@undiksha.ac.id ${ }^{2}$, Nyoman.gita@undiksha.ac.id ${ }^{3}$
}

\begin{abstract}
This research tried to formulate the model of formative assessment of integrated character education in schools by adopting the assessment model of Balinese cultural events. Various events of Balinese people, either religious or social events are solved through mutual cooperative. Members of the community involved vary widely, either in terms of age, experience, or profession, so that indirectly occurs the learning process and formative assessment. The formative assessment takes place in an integrated manner covering the components of performance, attitude, and behavior. Assessment takes place without instruments and the results accumulate into a person's track record. Feedback can be clues or suggestions. Uniquely, the assessment is done by everyone to everyone involved. Senior and junior assess each other, seniors assess each other, and junior assess each other also. Feedback is used as input to improve their selves. The assessment model can be implemented in schools in the form of direct observation with inventory. Inventory includes components of performance, attitude, and behavior. Assessment results can be integrated with the portfolio, so that the assessment results are more complete and more integrated.
\end{abstract}

Keywords - Assessment; Formative Assessment; Integrated Character Education

\section{INTRODUCTION}

Internet, television and other mass media continually preach brawls, drug use, traffic violations, anarchic behavior, and even terror behavior. This fact worries parents and people who care about the development of the young generation. In 2011character education in schools in Indonesia was began. Minister of national education at that time mentioned that the character education is implemented from the curriculum up to build culture in school [1]. The minister added that the character who wants to be built is not just politeness, but simultaneously built characters that can grow curiosity as an authorized capital to build creativity and innovation power.
Character education is about the acquisition and strengthening of virtues (qualities), values (ideals and concepts), and the capacity to make wise choices for a well-rounded life and a thriving society [2]. Character education is not run as a separate subject, but is integrated in all subjects. In principle, the development of culture and character of the nation is not included as a subject but integrated into the subjects, self-development, and school culture [3]. Character education is integrated within the school environment, whether in the curriculum, teaching strategies, or co-curricular programs. Character education therefore requires a standard program, standardized implementation, standard curriculum, standard partner work, and standard evaluation process.

Empirical experience shows there are some problems in implementing character education in an integrated manner in all subjects in school. The most difficult problem is in evaluation, especially formative evaluation. Formative evaluation is conducted during the learning process to find out what competencies have been achieved by students and identify gaps between student competencies with standard competencies to be achieved. The information is used by the teachers to plan the next learning in an effort to improve student learning outcomes. On the other hand, the teacher should also provide feedback to the students so that students know the progress of their learning. The teacher then provides guidance on where the student should move to improve the learning process. If the student response is correct, then the feedback becomes reinforcement for the students. Conversely, if the student's response is wrong, then the feedback becomes remedial learning for the students.

The difficult problem in the implementation of formative evaluation is to get information about the progress of learning outcomes regarding the character of students. Character education learning outcomes are more about affective domains (attitude) and psychomotor (behavior), such as honesty, responsibility, appreciation, selfconfidence, self-efficacy, and so on. Therefore, the 
evaluation process should be able to measure affective and psychomotor domains well. On this occasion, we try to formulate the evaluation model of event-based character education. The model was adopted from evaluation model of Balinese cultural event. Although it does not appear explicitly, either on the religious or social event of the Balinese community there is always a learning process and evaluation process. Community members who engage in events vary greatly in terms of age, experience, profession and so on. Therefore, in the activity occurs the learning process from senior community members to juniors, among seniors community, and also among juniors community. This study focused on the evaluation model which is very unique because it was done by everyone to all the people involved. The evaluation model is attempted to be formulated to be applied as an integrated character education evaluation in schools.

The development of academic competence and character building are the two main goals of education in schools. These two goals cannot be separated from the preparation of children to enter the workforce, further education, lifelong education, and to be good and responsible citizens. The development of academic knowledge contributes to the improvement of student's intellectual abilities and skills. Character education helps student to form attitudes and behaviors, such as honesty, integrity, respect, responsibility, self-discipline, and self-defense. Character education creates an environment that is expected to improve the effectiveness of learning activities. The hope is that no student can finish school by mastering academic knowledge but lacking in character. Benninga et al. [4] found that schools with good quality of character education qualities tend to produce graduates with higher academic ability.

Character education is implemented in an integrated manner within the school environment, whether in the curriculum, learning strategies, or co-curricular and extracurricular programs. Cooperation between family and community can identify and teach character values to students by example or role model while encouraging them to carry it out. Lickona [5] mentions that schools, families, churches, and other communities responsible for character education must be involved in the evaluation of character education for a common goal. In recent years, the school has the capacity to be able to carry out well and correctly character education. Teachers at school act as people, who help students to shape themselves for the better, not just help the students to improve competencies, skills, or techniques.

Students were encouraged to more appreciate the good experiences gained from the school and to avoid the unfavorable experiences gained from their group or mass media. Group habits and mass media often have a negative effect on the character of the students. Today, destructive tendency groups are growing. Similarly mass media, such as television, movies, magazines, newspapers, mobile phones or the internet often present violence, drug use, sexual behavior aberrations, theft, and academic fraud. Collaboration of internet and mobile phones even now has opened up opportunities for everyone to become a reporter. As a result, pornography, terrorist, narcotics, and so very easily spread through facebook, twitter, instagram, whatsup, and other features. Therefore, the role of teachers in schools is not limited to the application of various models to assist the transfer of information and skills to students, but to foster the development of students in their entirety.

Spears [6] mentions that the character has much to do with the essential traits exhibited by a person. Indeed, character education is focused on the affective and psychomotor domains. Hence, exemplary factors become an important component of learning while observation factors become an important component in the evaluation. It is difficult for the teacher to observe all of their student's attitude and behavior because of the limitation of time and energy. It means that it is necessary to develop character education evaluation model that able to overcome the limitations of time and energy by involving all elements of the school. One model of character education evaluation developed is that everyone evaluates everyone. This model is adopted from Balinese culture-based evaluation.

\section{METHOD}

This research used qualitative approach. The sample was determined by snowball technique by selecting one initial respondent then move on to the next respondent based on the data requirement and the respondent's consideration at the time. The respondents were community leaders who are accustomed to engaging in events with mutual cooperation and even once a leader in the intended events. Data were collected by in-depth interview techniques in natural settings. The data collected included evaluation components, qualification levels, recording techniques, decision-making techniques, and feedback techniques. The collected data were analyzed using qualitative data analysis model of Miles and Huberman [7], consisting of three activities namely data reduction, data presentation, and verification.

\section{RESULT}

The study found that assessment of cultural events in Bali included the components of work processes, performance, commitment, honesty, cooperation, caring, responsibility, tolerance, appreciation, speech, communication ethics, and behavior. This finding is similar to eleven character education criteria formulated by DeRoche \& Williams [8], namely concern, cooperation, commitment, courage, change, relationship, coherence, consensus, communication, culture, and criticality. Differences occur because the assessment of character education based on Balinese culture is done in an integrated manner with performance assessment, while DeRoche \& Williams formulation only contains character education criteria.

Generally, character education assessments are conducted by assessors (both teachers and other staff) to learners. Different things happened in the process of assessment of character education based on Balinese culture, 
where the assessment was done to everyone by everyone present. Everyone present in cultural events have the same rights and obligations because they are all citizens. The difference only exists at the level of seniority classified by age and experience differences. Here senior assess junior, junior assess the other junior, and senior assess the other senior. Assessment is done sporadically by using qualitative measures and not explicitly using rubrics. Assessment results are only stored in memory. The result of the assessment in one event is related to the assessment of the next event, so it becomes a kind of track record. The track record poses a positive thing for this assessment model that is the appearance of a role model in Skinner terms called significant others. Another positive point derived from such an assessment model is the occurrence of some sort of sublimation effect, in which the deficiencies in one activity will try to be covered with an excess on the other. Nevertheless, this assessment model cannot be separated from the weakness, among others the effect of stereotype, namely embedding a nickname to someone because too often raises a particular word, attitude, or behavior.

The adoption of a character education assumption model above can be done by packing it into school activities, both in class and outside the classroom. During classroom learning activities, assessment can be done by teachers or other students. While for out-of-class activities, such as devotional work, prayer, or scouting, the assessment may also be performed by other school staff involved, such as employees, technicians, librarians and even principals.

The original assessment model above does not use the instrument. In order to have a standard assessment process, it is necessary to develop relevant instruments. The most relevant assessment instrument to support an integrated character education assessment above is inventory. Inventory is an evaluation instrument in the form of a number of statements with a range of scores to be selected. The scope of the inventory moves from one pole to another. For example an inventory in which contains a statement about the ordinance of communicating. The range of scores provided for example 1 to 10 like Table I, which 1 is at the ugly pole and 10 is at the well pole. The appraiser will give the scores according to the observations made. In accordance with the integrated character education components that are already found, inventory for an integrated character education assessment can be formulated as follows.

TABLE I. THE RANGE OF SCORES

\begin{tabular}{|l|cccccccccc|}
\hline Component & \multicolumn{10}{|c|}{ Score } \\
\hline & Bad Good & & & & \\
\hline Work Process & 1 & 2 & 3 & 4 & 5 & 6 & 7 & 8 & 9 & 10 \\
\hline Performance & 1 & 2 & 3 & 4 & 5 & 6 & 7 & 8 & 9 & 10 \\
\hline Commitment & 1 & 2 & 3 & 4 & 5 & 6 & 7 & 8 & 9 & 10 \\
\hline Honesty & 1 & 2 & 3 & 4 & 5 & 6 & 7 & 8 & 9 & 10 \\
\hline Cooperation & 1 & 2 & 3 & 4 & 5 & 6 & 7 & 8 & 9 & 10 \\
\hline Concern & 1 & 2 & 3 & 4 & 5 & 6 & 7 & 8 & 9 & 10 \\
\hline Responsibility & 1 & 2 & 3 & 4 & 5 & 6 & 7 & 8 & 9 & 10 \\
\hline Tolerance & 1 & 2 & 3 & 4 & 5 & 6 & 7 & 8 & 9 & 10 \\
\hline Appreciation & 1 & 2 & 3 & 4 & 5 & 6 & 7 & 8 & 9 & 10 \\
\hline Speech & 1 & 2 & 3 & 4 & 5 & 6 & 7 & 8 & 9 & 10 \\
\hline Communication Ethics & 1 & 2 & 3 & 4 & 5 & 6 & 7 & 8 & 9 & 10 \\
\hline Behavior & 1 & 2 & 3 & 4 & 5 & 6 & 7 & 8 & 9 & 10 \\
\hline & & & & & & & & & \\
\hline
\end{tabular}

The majority of assessments were conducted through observation while working. A senior while doing his work conducted an assessment of the junior being supervised by observing his performance, attitude, and behavior. Direct or indirect praise was given to his juniors who performed well, be nice, or behave well. In contrast, reminders of clues, admonitions, or examples will be given when the juniors perform poor performance, mismatches in attitude or errors in behavior. Fellow senior or fellow juniors also occur assessment process. One senior conducted an assessment of another senior, as well as one junior conducted an assessment of another junior. Intersenior or inter-junior will discuss the results of each assessment. Discussion results were used to improve themselves. The very unique thing here was that juniors also conducted assessments of their seniors. A junior conducted an assessment of his or her senior in terms of approach, communication, attitude, and behavior. It's just that a junior is sometimes reluctant to give feedback to his senior, so they convey through friends or other seniors.

Something similar can happen in an atmosphere at school. Assessment feedback on students will be easy to deliver, while assessment feedback on teachers or other school staff, both by students and fellow staffers will be more difficult to convey. This happens because the habit of hesitating to assess teachers or colleagues. This should not happen because the goal to be achieved is very 
important, namely self-improvement. The approach that can be taken is not to include the name of the appraiser, then made a recap by the principal. Assessment results and feedback were conveyed by the principal through a forum, such as a coordination meeting or at a friendly event.

\section{CONCLUSION}

Everyone who attends the cultural event in Bali is a citizen of the same duty, even if there is a difference of age or experience among them. Their main goal is to work together to complete the work to succeed the event that is facing. The learning process also occurs when they were working together. The more senior citizens are educating their junior, as well as those skilled in one area will educate others in the field. Indirectly, the people involved in the event conduct the assessment sporadically. Assessment is done in an integrated manner, whether it concerns performance, attitude, or behavior. The very unique thing is that assessment is done to everyone by everyone present.

When this assessment model is implemented in schools, there will be student assessments by teachers, peers, and other school staff, as well as assessments of school staff by students and by other staff colleagues. This is certainly very interesting because it gives many advantages. Assessment of students by anyone is common in an effort to improve student learning outcomes, as well as cognitive, affective, or psychomotor. Assessment of school staff by students and other staff is also very necessary. Principals, teachers, and other staff should be role models for students. Therefore, they must seek to improve themselves. In addition to self-evaluation, self-improvement can also be made on the basis of assessments by students and other staff colleagues.

\section{REFFERENCES}

[1] Suaramerdeka.com, May 2, 2011.

[2] Center for Curriculum Redesign. 2015. Character Educationfor the 21st Century: What Should Students Learn?. Boston, MA.

[3] Kemendikbud, March 28, 2013, Pendidikan Karakter Melekat pada Semua Mata Pelajaran.

[4] Benninga, et.al. "The Relationship of Character Education and Academic Achievement in Elementary School", Journal of Research in Character Education, 1(1), 2003, pp. 19-32.

[5] Lickona, Thomas. 2001.The Teacher's Role in Character Education, Boston: Boston University.

[6] Spears, Larry C., Character and Servant Leadership: Ten Characteristics of Effective, Caring Leaders, The Journal of Virtues \& Leadership, Vol. 1 Iss. 1, 2010

[7] Miles, M.B. and Huberman, A.M. 1994. Qualitative data analysis: an expanded sourcebook. Thousand Oaks, CA: Sage Publications.
[8] DeRoche, Edward F. \& Mary M. Williams. 1999.Educating Heart and Minds: A Comprehensive Character Education Framework. London: Kogan Page Limited. 
